\title{
Applicability of Forensic Accounting to Reduce Fraud and its Effects on Financial Statement of Jordanian Shareholding Companies From the Perspective of Judiciary and Certified Public Accountant
}

\author{
Abdussalam Mahmoud Abu Tapanjeh ${ }^{1}$ \& Ashwaq Rateb Al Tarawneh ${ }^{1}$ \\ ${ }^{1}$ Accounting Department, Mutah.University, Jordan \\ Correspondence: Prof. Dr. Abdussalam Mahmoud Abu Tapanjeh, Dean of the School of Business, Accounting \\ Department, Mutah University, Jordan.
}

Received: October 30, 2019

Accepted: January 28, 2020

Online Published: March 25, 2020

doi:10.5430/ijfr.v11n2p436

URL: https://doi.org/10.5430/ijfr.v11n2p436

\begin{abstract}
This research aimed to investigate the applicability of forensic accounting to reduce fraud and its effects on the financial statement of Jordanian Shareholding Companies from the perspective of Judiciary and Certified Public Accountant. This study used a descriptive-analytical method. To elicit data from the participants, the researcher used a questionnaire survey distributed over a randomly selected sample from competent authorities in the financial criminal cases in the Jordanian Courts (Judges, and Public Prosecutors), Certified Public Accountants licensed to practice auditing, and chartered accountants with expertise in financial cases in the Jordanian courts, to investigate their perceptions and views about the applicability of Forensic Accounting to reduce fraud and its effects on the financial statement of Jordanian Shareholding Companies.

The researcher used the statistical analysis program (SPSS) to analyze the collected data besides the regression equation test, the statistical differences test for the non-scientific samples.

The findings of the study showed that there is a necessity for providing the requirements, components, procedures, and.activities of Forensic Accounting in Jordan to reduce fraud and its effects on the financial statement of Jordanian Shareholding Companies from the perspective of Judiciary and Certified Public Accountant. Also, the results of the study indicated that there is a difference between judicial authority and Certified Public Accountants' perceptions. Based on these findings, the study lists a set of recommendations the most important of which is adopt the requirements and principles of applying Forensic Accounting by decision-makers and professional organizations, and to establish an official and independent professional association of Forensic Accountants to develop forensic accounting standards and legislation, and to raise the awareness of the judicial authorities concerning the importance of the concept of Forensic Accounting in resolving financial criminal cases, and the extent of its contribution in rationalizing judicial decisions.
\end{abstract}

Keywords: forensic accounting, legal accounting, criminal lawsuits, fraud

\section{Introduction}

Financial statements are considered the basic and final product of the accounting work and the main source to present the financial data that are beneficial to many entities that have a direct or indirect relationship with economic units such as managers, stockholders, control authorities, governmental entities, and potential investors. Due to the importance of these statements, it should include data that have certain qualitative characteristics to achieve quality requirements and to emphasize credibility and confidence to stakeholders to actually and fairly reflect the reality of the corporation and its activities.

The spread of financial fraud in the business world and pursuit of many managers to beautify their organizations' image to the stakeholders have produced world crises and the collapse of some giant corporations such as Enron the giant energy corporation and the accusation of Arthur Andersen of this collapse and of committing fraud in the financial statements since it is responsible for the auditing process by exploiting the diversity of accounting alternatives. In addition to the fact that auditors have used some gaps in the accounting principles and policies to achieve their interests at the expense of other parties. Despite the existence of International Auditing Standards and International Financial Reporting Standards (IFRS) financial crime rates and fraud have continued to increase, either 
due to negligence or complicity of legal auditors also sometimes audit and internal audit committees lack the necessary expertise and experience to uncover the facts behind the fraud. Moreover, the functions of the Certified Public Accountants do not include the process of investigating fraud in financial statements. Its primary function is to express an opinion on the appropriateness of the financial report prepared by the Company's management with the requirements of both IFRS and International Auditing Standards.

This has resulted in increased doubts among the shareholders, lenders, and investors about the integrity and credibility of the financial statements and the extent of their conformity with reality. The rates of financial disputes have increased and the judiciary needs experts or accounting consulters to utilize their expertise and the depth of their investigations and their opinion about criminal cases involving financial fraud (Ahmed, 2013). The emergence of a specialized entity was an essential matter to protect the financial system of companies so that they can find a mechanism to control the validity of the financial statements using special expertise and skills to carry out deep investigations concerning fraud known as Forensic Accounting as a profession that represents an integrated framework for accounting. As a result, many countries have been interested in Forensic Accounting. The Canadian Institute of Forensic Accountants has issued a set of special standards for the practice of Forensic Accounting. Also, the Institute, in collaboration with many professional and university organizations, has formed a coalition concerned with Forensic Accounting, as well as the American Institute of Certified Public Accountants has established specialized professional entities to award a degree in Forensic Accounting. In the Arab world, Forensic Accounting has become the focus of accountants, auditors, law enforcement and judiciary. A profession looks beyond numbers in dealing with the facts. It utilizes law and investigation skills with the aid of accounting and auditing skills to be present in the courts to resolve financial disputes, to make fair and transparent litigation and to detect fraud and to make reports about it.

This study tackles one of the recent and important fields of accounting that would meet many future needs. The study aims at exploring the possibility of applying Forensic Accounting to reduce fraud and its effects on the financial statements of Jordanian public holding companies from the perspectives of the judiciary and the Certified Public Accountants.

\section{The Problem of the Study and Its Questions}

The misguided accounting practices in the financial statements and the frauds committed by some accounting and auditing offices have led to huge financial collapses faced by major international companies. The frauds have been exacerbated in recent times, especially in light of the huge economic and technological developments. The problem of the study and its questions

The misguided accounting practices in the financial statements and the frauds committed by some accounting and auditing offices led to huge financial collapses faced by major international companies. The frauds have been exacerbated in recent times, especially in light of the huge economic and technological developments. Some statistics indicate that the losses resulting from financial fraud in the world estimated to be one trillion dollars a year, or about $7 \%$ of the total world trade, the Arab's world share of them is about (100) billion dollars annually (Kubaisi, 2016). As a result of the high risk of illegal financial practices, there is an urgent need to look for modern accounting mechanisms and means that concern about the nature of the financial statements. There is also, a need for professional accountants who have a set of integrated skills in accounting and auditing combined with financial expertise as well as the skill of investigations and work within a legal framework that provides sufficient evidence to control fraud.

Forensic accounting has emerged, as it contributes to the needs of many relevant parties and provides a mechanism capable of reducing fraud, as well as providing a range of services related to internal investigations and contributing to resolving financial disputes between companies and any other parties.

Due to the importance of this field, the study problem could be identified by the following main questions:

1. What is the possibility of providing the requirements of applying forensic accounting to reduce fraud and its effects in the financial statements of the Jordanian public shareholding companies from the viewpoints of the judiciary and the certified public accountant?

2. What is the possibility to provide the component of applying forensic accounting to reduce fraud and its effects in the financial statements of the Jordanian public shareholding companies from the viewpoints of the judiciary and the certified public accountant?

3. What is the possibility of applying criminal accounting procedures and activities as an independent external profession to reduce fraud and its effects on the financial statements of Jordanian public shareholding companies 
from the viewpoints of the judiciary and certified public accountant?

4. Are there any statistical differences in the dimensions of forensic accounting attributed to job title (judicial authority, certified public accountant)?

\subsection{Objectives of the Study}

The main objective of this study is the attempt to explore the possibility of applying criminal accounting to reduce the fraud and its effects on the financial statements of the Jordanian public shareholding companies from the viewpoints of the judiciary and the certified public accountant. This objective is achieved through the followings:

1) To identify the possibility of providing the requirements of applying Forensic accounting to reduce fraud and its effects on the financial statements of the Jordanian public shareholding companies from the viewpoints of the judiciary and the certified public accountant. The following Sub-objectives are branched from this objective:

a) To identify the possibility of providing research and investigation services to apply forensic accounting to reduce fraud and its effects on the financial statements of Jordanian public shareholding companies from the viewpoints of the judiciary and the certified public accountant.

b) To identify the possibility of providing legal support services for applying forensic accounting to reduce fraud and its effects on the financial statements of Jordanian public shareholding companies from the viewpoints of the judiciary and the certified public accountant.

2) To identify the possibility of providing the components of applying forensic accounting to reduce fraud and its effects on the financial statements of the Jordanian public shareholding companies from the viewpoints of the judiciary and the certified public accountant.

a) To identify the possibility of providing the appropriate skills and practical experience that must be enjoyed by the forensic accountant to apply forensic accounting to reduce fraud and its effects on the financial statements of Jordanian public shareholding companies, from the viewpoints of the judiciary and the certified public accountant.

b) To identify the possibility of providing the characteristics that must be enjoyed by the forensic accountant to apply forensic accounting to reduce the fraud and its effects on the financial statements of the Jordanian public shareholding companies from the viewpoints of the judiciary and the certified public accountant.

3) To identify the applicability of forensic accounting procedures and activities as an independent external profession to reduce fraud and its effects on the financial statements of Jordanian public shareholding companies from the viewpoints of the judiciary and the certified public accountant.

4) To identify the extent of the presence of statistical differences in the dimensions of criminal accounting, which are attributed to the job title (judicial authority, certified public accountant).

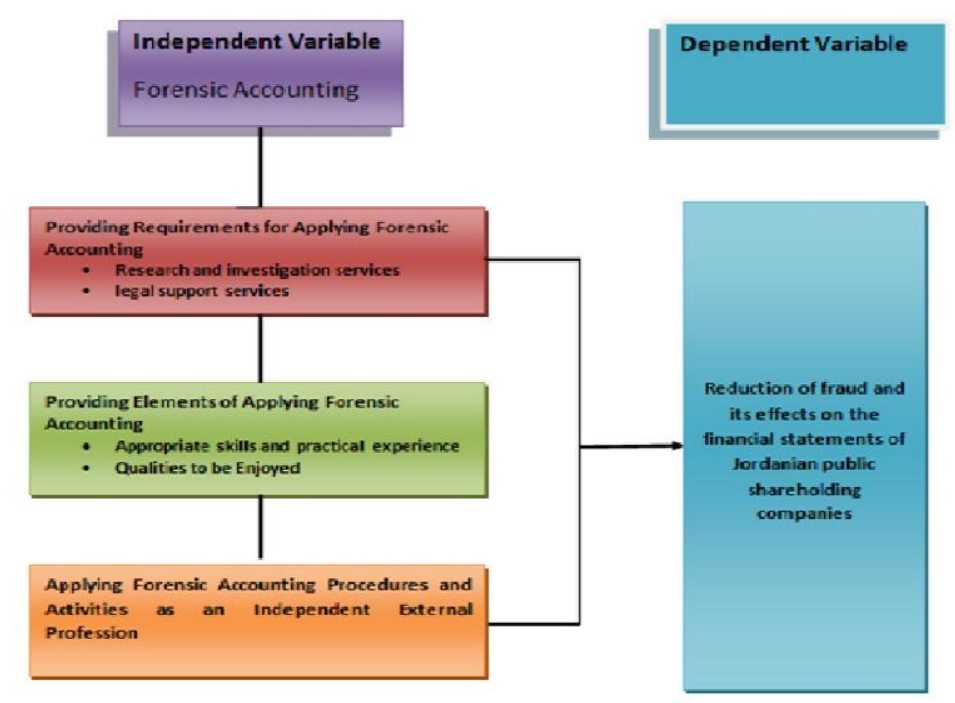

Study Model 


\subsection{The Hypothesis of the Study}

Based on the problem of the study and its objectives, the following main hypotheses were formulated:

The first main hypothesis: the possibility of providing the requirements for applying forensic accounting has no statistically significant impact in limiting fraud processes and its effects on financial statements in Jordanian public shareholding companies from the viewpoints of the judiciary and the certified public accountant at $\propto \leq 0.05$.

From this hypothesis, the following sub-hypotheses are branched:

- The first sub-hypothesis: the possibility of providing research and investigation services to apply forensic accounting has no statistically significant impact in limiting fraud processes and its effects on financial statements in Jordanian public shareholding companies from the viewpoints of the judiciary and the certified public accountant at $\propto \leq 0.05$.

- The second sub-hypothesis: the possibility of providing legal support services for applying forensic accounting has no statistically significant impact in limiting fraud processes and its effects on financial statements in Jordanian public shareholding companies from the viewpoints of the judiciary and the certified public accountant at $\propto \leq 0.05$.

The second main hypothesis: the possibility of providing the components of applying forensic accounting has no statistically significant impact in limiting fraud processes and its effects on financial statements in Jordanian public shareholding companies from the viewpoints of the judiciary and the certified public accountant at $\propto \leq 0.05$.

From this hypothesis, the following sub-hypotheses are branched:

- The first sub-hypothesis: the possibility of providing the appropriate skills and practical experience that must be enjoyed by the forensic accountant to apply forensic accounting has no statistically significant impact in limiting fraud processes and its effects on financial statements in Jordanian public shareholding companies from the viewpoints of the judiciary and the certified public accountant at $\propto \leq 0.05$.

- The second sub-hypothesis: the possibility of providing the characteristics that must be enjoyed by the forensic accountant to apply forensic accounting has no statistically significant impact in limiting fraud processes and its effects on financial statements in Jordanian public shareholding companies from the viewpoints of the judiciary and the certified public accountant at $\propto \leq 0.05$.

The third mean hypothesis: the applicability of forensic accounting procedures and activities as an independent external profession has no statistically significant impact in limiting fraud processes and its effects on financial statements in Jordanian public shareholding companies from the viewpoints of the judiciary and the certified public accountant at $\propto \leq 0.05$.

The fourth mean hypothesis: there are no statistical differences in the dimensions of Forensic accounting attributed to the job title (judicial authority and the certified public accountant) at $\propto \leq 0.05$.

\section{Theoretical Framework}

Forensic accounting is defined as "a profession resulted from the integration process between the skills of accountants and auditors as well as investigation skills" (Blessing, 2015). Some consider forensic accounting as "the application of financial skills, investigative skills in unresolved cases within the framework of the rules of evidence, forensic accounting as a system or specialty includes financial expertise, knowledge of fraud, a correct understanding of the business reality and the legal system environment, and its development has been achieved by on-the-job training, in addition to experience with investigative officers and the legislation council" (Augustine and Uagbale-Ekatah, 2014). Al-Saad (2013) argues that forensic accounting "focuses beyond numbers through combining accounting and legal knowledge to help judges to recognize what is right and to achieve justice; in other words, it seeks to adapt accounting to support and resolve problems related to disputes and legal proceedings within the framework of legal systems and procedures". Al-Khalidi (2014) defined forensic accounting as "accounting that provides an accounting analysis that is convenient to the courtroom and which is used as a basis for discussion and debate and for reaching a final resolution about the conflict, it is a branch of accounting in the modern era, incorporating accounting with law, auditing, computer science, and the Internet. This interference between these different sciences helps the investigation experts to discover fraud and financial crimes and to provide sufficient evidence for the specified entities following the principles, methodology and irrefutable evidences valid for conviction. "The study of Singleton, et al. (2010) suggests that the emergence of forensic accounting dates back to 1817 as a result of a bankruptcy case involving a financial dispute in a Canadian court, which led to the summoning of the accountant who investigated this case to benefit from his experience in the court as an expert witness. From Crumbley's perspective, this accountant was the first forensic 
accountant in history and the beginning of the appearance of forensic accounting as a profession independent of a certified accountant. The study (Islam, et al., 2011) pointed out that forensic accounting appeared in 1824 when an advertisement was published in a newspaper for the first time in the city of Glasgow in Scotland, calling rulers, lawyers, and accountants to investigate fraudulent activity in a certain lawsuit. In 1900 it began to appear in the United States and England, where the reliance on federal income tax increased the need for forensic accountants because of tax evasion. As a result of these operations, United States Tax Service has developed many forensic techniques used to detect tax evaders, as the first tax evasion revealed by forensic accounting is related to the criminal gangster Al Capone. During the Second World War, the FBI recruited more than 500 forensic accountants to carry out checks, surveillance and monitoring of financial transactions (Jubouri and Khalidi, 2013). Due to the prevailing conditions in the business world and the use of financial statements by many corporations to improve the financial situation, the accounting profession is undergoing a deep crisis of confidence that can be expressed in a crisis of ethics stemming from the control of greed and narrow private interests (Al-Monoufi, 2011). There is an urgent need to seek modern mechanisms and means to investigate fraud by using specialized expertise and skills to conduct the necessary investigations to gather evidence to be submitted to the specialized judicial authorities. As well as there is a need for an in-depth study of the role of forensic accounting to qualify accountants scientifically and practically to work as experts or advisers to support criminal proceedings in detecting fraud (Khalil, 2017). Forensic accounting is based on a combination of multiple expertises to cover a wide range of investigative disciplines, criminal information technology, support for criminal proceedings, settlement and resolution of disputes, to meet the needs of investors and lenders and workers in the law and the judiciary and all beneficiaries of the data contained in the financial statements of different companies. The forensic accountant is required to be able to understand the ideas and axioms quickly since the nature of the work imposes that the forensic accountant should enjoy a knowledge in accounting, legal and financial procedures and methods of investigation (Al-Jaleeli, 2012). Al-Said (2010) considered forensic accounting the most important tool to meet the needs of the judiciary in the settlement and resolution of financial disputes through the forensic accountant to investigate these matters wisely and rationally to prove and clarify the facts so that they are supported by physical evidence and submitted to the judiciary. Therefore, it is necessary to have some important components and tools in forensic accounting, so that it can play its role effectively in combating and dealing with the fraud and various financial corruption in the financial statements (Khalil, 2017). Radhi (2011) pointed out that forensic accounting contributes to the provision of investigation service, which includes criminal investigation services, assessment of economic loss of business, fraud investigation, disputes of partnerships and shareholders, claims of personal injury, business interruption cases such as loss of property rights and lack of integrity of corporate employees. Also, forensic accounting contributes to the provision of legal support services. It includes the services of the expert witness by presenting his or her opinion in the courts in cases of dispute, advisory services, and other services in which the forensic accountant may work as an expert judge, expert arbitrator or court expert. The study was conducted by the American Institute of Certified Public Accountants (AICPA, 2006).

The two researchers, from the previous discussion, believe that forensic accounting is a branch of modern accounting science that combines integrated knowledge of accounting, auditing and legal matters related to financial operations, computer science and the Internet, in addition to a set of skills for investigation, verification and in-depth understanding of accounting processes and legal knowledge. This integration helps the forensic accountant to express an independent professional opinion by providing a detailed report based on full knowledge and expertise aimed at providing adequate accounting analysis to the judiciary authority to resolve financial disputes and to support criminal proceedings, and to provide sufficient evidence to control fraud and ensure the reliability of financial statements.

\section{Previous Studies}

\begin{tabular}{lll}
\hline Title \& Researcher & Objective & Results \\
\hline Developing the Role of the & The main objective of the & The study concluded the validity of the hypothesis \\
Forensic Auditing to & research is drafting an on which the researcher proposed and thus the \\
Prevent Fraud Financial & intellectual framework of a validity of the proposed framework for developing \\
Corruption in Business & proposal to develop the role of & the role of judicial review and thus the ability to \\
Organizations and the Forensic Auditing to prevent achieve the credibility of accounting information. \\
Achieve Credibility & or reduce fraud and financial \\
Accounting Information corruption and determine its & \\
Empirical Study, (Khalil, impact on the credibility of
\end{tabular}




\begin{tabular}{ll}
\hline 2017). & accounting information. \\
\hline Mapping Forensic & This study explores the nature of \\
Accounting in the UK, & forensic accounting in the UK, it \\
(Hegazy, et. al., 2017) & investigates how forensic \\
& accounting is perceived, the \\
& profile of those working in the \\
& field, types of services offered, \\
& essential knowledge and skills \\
& required.
\end{tabular}

An Investigation of the Factors that Impact the Perceived Value of

Forensic Accounting Certifications, (Domino et al., 2017)
This research aims to evaluate the perceived value of forensic accounting certifications in the USA.
The study pointed out that the results should be the subject of interest of international accounting, especially professional accounting entities, in addition to providing guidance that may affect how they deal with this growing field. The study also pointed out that the absence of specific professional institutions concerned with forensic accounting pushed most of the studies conducted to define forensic accounting services under a single comprehensive umbrella without paying attention to how their various branches affect the qualifications and responsibilities required, the services provided by forensic accountants, as well as their failure to train professional institutions on a large scale to prepare Qualified persons to perform the required tasks.

The study extended prior research on forensic accounting certifications, providing empirical evidence regarding its perceived value, which can have implications for training and hiring professional accountants to reduce fraud. The results of the study help academics advise students on the value of certificates for a career in criminal accounting, Employers looking for a way to distinguish between criminal accountants.
The Role of Forensic Accounting in Combating the Menace of Corporate Failure, (Aduwo, 2016)

\section{This paper aims to conceptually review the impact of forensic accounting toward utilizing professional judgments, accounting skills, auditing, and law procedures to fight the dreaded disease of corporate liquidation}

An Empirical The study aimed to

Investigation of the Forensic Accounting from Judicial and Forensic Accountant Point of View in Jordan, (Alkubaisi, 2016) investigate the importance of forensic accounting in resolving disputes of a financial nature and in a fair manner in Jordan, based on the views of both the judiciary and the forensic accountant.
The study concluded that forensic accountants must be well trained in many areas to be able to cope with fraud and address the global risk of corporate failure. The study also contributed to increasing knowledge by expanding existing studies on the effectiveness of forensic scrutiny in reducing the risk and failure of companies.

The study found that the current reality of forensic accountability is far from achieving justice in resolving conflicts as it should be. There are no academic, governmental or private entities or institutions that are interested in forensic accounting, the introduction of teaching material or the training skills necessary to qualify the forensic accountant. There is a difference between the views of the two samples, that is, the sample of judges was more interested in criminal accounting than the sample of forensic accountants.

\footnotetext{
Analytical study of the role of forensic accounting in the development of accounting mechanisms to combat financial and administrative corruption by applying to companies listed on the Egyptian Stock Exchange, (Ahmed, 2013)

The main objective of the study is to analyze the role of forensic accounting in developing accounting mechanisms to combat financial and administrative corruption cases by applying to companies listed on the Egyptian Stock Exchange.
}

The study found that there is a need for forensic accounting mechanisms, whether for students of accounting in universities or accountants and auditors, and it was found that the effects of forensic accounting mechanisms were positive on the expertise, skills, and knowledge of the study sample in a manner that qualifies them to combat cases of fraud and financial and administrative corruption within companies. 


\subsection{What Distinguishes This Study From Previous Studies?}

Through reviewing previous studies that dealt with the subjects of forensic accounting and financial fraud, which was conducted in different environments addressing several aspects with different objectives, variables, and findings. The studies have shown that forensic accounting professions effective in reducing fraud at the Arab and international levels; as it contributes to the diagnosis of the reality of companies in a real and fair manner to achieve the interests of all parties involved.

Accordingly, this study was conducted addressing three main dimensions to measure the effectiveness of its role in reducing fraud and its effects on the financial statements in Jordanian public shareholding companies represented in the possibility of providing the requirements for applying forensic accounting, the possibility of providing the components for applying forensic accounting, and the applicability of forensic accounting procedures and activities as an independent external profession. This was done through reviewing the views of the competent parties, which form the primary reference and the main pillar in the case of financial crime cases in Jordanian Judicial Council represented by trail courts judges, Attorneys General, and the perspectives of certified legal accountants and practicing auditing profession and accredited by the Association of Jordanian Certified Accountants, as well as the perspectives of legal accountants who have expertise in financial matters in Jordanian courts (financial experts in courts). This study is considered the first study of its kind in the Hashemite Kingdom of Jordan and perhaps in the Arab region, which dealt with these dimensions together from those who are most qualified to understand and to assess the possibility of applying forensic accounting in the Jordanian environment.

\section{Methodology and Design}

This study was based on the analytical descriptive approach, founded on the study of the problem and its characteristics in addition to describing the quality of the relationship between its variables.

\subsection{The Population of the Study and Its Sample}

The population of the study is composed of four main categories, which are the most aware and understanding of the problem of study, and the ablest to assess the possibility of applying forensic accounting to reduce fraud and its effects on the financial statements in Jordanian companies. These categories are:

First: Licensed Chartered Accountants who practice the auditing profession totaling (418) Certified Public Accountants according to the statistics of the Jordanian Society of Chartered Accountants in 2018, a random sample of $(50 \%)$ of the study population has been selected and included (209) Chartered Accountants. After reviewing the copies of the Questionnaire, (195) copies were adopted for statistical analysis purposes.

Second: Chartered accountants who are experienced in financial cases in the courts of Jordan (financial experts in the courts), who are (47) accountants according to the statistics of the Jordanian Association of Chartered Accountants in 2018. A random sample of $50 \%$ of the study population of total (24) accountants as financial experts, and after checking the questionnaire, (22) copies were adopted for statistical analysis.

Third: Trail judges specialized in financial crime cases in the Jordanian courts, which are (116) accredited judges according to the statistics of the Jordanian Judicial Council in 2018. A random sample of (70\%) of the study population was selected including (81) trail judges after reviewing all distributed questionnaires were approved for statistical analysis purposes.

Fourth: Attorneys General in charge of financial crime cases in the Jordanian courts, which are 32 accredited public attorneys according to the statistics of the Jordanian Judiciary Council at the beginning of 2018. A random sample of (78\%) was selected from the study population, including (25) Attorneys General, after reviewing all distributed questionnaires were approved for statistical analysis purposes.

\section{Testing the Study Hypothesis}

\subsection{Results Related to Testing First Main Hypothesis}

The first hypothesis states, "the possibility of providing the requirements for applying forensic accounting has no statistically significant impact in limiting fraud processes and its effects on financial statements in Jordanian public shareholding companies from the viewpoints of the judiciary and the certified public accountant at $\propto \leq 0.05$ ". To verify the validity of this hypothesis, a simple regression equation was applied to study the impact of providing the requirements for applying forensic accounting (investigation services and legal support services) to limit fraud and its effects on financial statements in Jordanian public shareholding companies, as illustrated in Table 1. 
Table 1. The results of applying simple linear regression to test the first main hypothesis

\begin{tabular}{|c|c|c|c|c|c|}
\hline Dependent variable & Independent variable & Beta & $\mathrm{T}$ & Sig. & VIF \\
\hline & Constant & .794 & 6.677 & 0.000 & \\
\hline \multirow{4}{*}{\begin{tabular}{lr}
\multicolumn{2}{l}{ Limiting fraud and its } \\
effects on & financial \\
statements & in \\
Jordanian & public \\
shareholding & \\
companies &
\end{tabular}} & $\begin{array}{l}\text { providing the requirements for } \\
\text { applying forensic accounting }\end{array}$ & .510 & 8.016 & 0.000 & 1.000 \\
\hline & $\mathrm{R}^{2}$ & \multicolumn{4}{|l|}{.167} \\
\hline & $\mathrm{F}$ & \multicolumn{4}{|c|}{64.260} \\
\hline & SIG & \multicolumn{4}{|c|}{0.0000} \\
\hline
\end{tabular}

Table 1 illustrates the results of the simple regression equation to test the first hypothesis; it is obvious that there is a statistically significant impact of providing the requirements for applying forensic accounting in limiting fraud and its effects on financial statements in Jordanian public shareholding companies. Since $\mathrm{R}^{2}$ interpretive equals $16.7 \%$ value, the independent variables of the dimensions of providing the requirements for applying forensic accounting which include: investigation services and legal support services have interpreted $16.7 \%$ of the dependent variable that is limiting fraud and its effects on financial statements in Jordanian public shareholding companies. This indicates that other variables have not been included in the study model that is responsible for $83.3 \%$ of limiting fraud and its effects on financial statements in Jordanian public shareholding companies. The regression model is statistically significant as SIG. value equals 0.000 which is less than 0.05 implying that the model is statistically accepted. According to the value of VIF that is less than 5 implying all dimensions of the dependent variable are accepted and there is no Collinearity problem between the variables. As well as, the value of the Sig-T was statistically significant at $\alpha \leq 0.05$ was (0.000) and the value of the beta coefficient equals $(0.510)$ which means that the null hypothesis is rejected. So that providing the requirements for applying forensic accounting has a positive impact on limiting fraud and its effects on financial statements in Jordanian public shareholding companies. This indicates that when the possibility of providing the requirements for applying forensic accounting is increased by one unit, then limiting fraud will be increased by $(16.7 \%)$.

Based on these results, the alternative hypothesis will be accepted that states "the possibility of providing the requirements for applying forensic accounting has a statistically significant impact in limiting fraud processes and its effects on financial statements in Jordanian public shareholding companies from the viewpoints of the judiciary and the certified public accountant at $\propto \leq 0.05$."

\subsubsection{Results Related to Testing the Sub-hypothesis of the First Main Hypothesis}

1. The results of the test the first sub-hypothesis that states "the possibility of providing investigation services for applying forensic accounting has no statistically significant impact in limiting fraud processes and its effects on financial statements in Jordanian public shareholding companies from the viewpoints of the judiciary and the certified public accountant at $\propto \leq 0.05$. To verify the validity of this hypothesis, simple regression equation was applied to study the impact of providing investigation services to limit fraud and its effects on financial statements in Jordanian public shareholding companies, as illustrated in Table 2.

Table 2. The results of applying simple linear regression to test the first sub-hypothesis

\begin{tabular}{|c|c|c|c|c|}
\hline Dependent variable & Independent variable & Beta & $\mathrm{T}$ & Sig. \\
\hline & Constant & .973 & 7.960 & .000 \\
\hline \multirow{4}{*}{$\begin{array}{llr}\text { Limiting fraud and its } \\
\text { effects on financial } \\
\text { statements in Jordanian } \\
\text { public } & \text { shareholding } \\
\text { companies } & & \end{array}$} & providing investigation services & .413 & 6.293 & .000 \\
\hline & $\mathrm{R}^{2}$ & .110 & & \\
\hline & $\mathrm{F}$ & 39.601 & & \\
\hline & SIG & 0.0000 & & \\
\hline
\end{tabular}

Table 2 illustrates the results of the simple regression equation to test the first sub-hypothesis, it is obvious that there is a statistically significant impact of providing investigation services in limiting fraud and its effects on financial 
statements in Jordanian public shareholding companies. Since $\mathrm{R}^{2}$ interpretive value equals $11 \%$, the investigation services have interpreted $11 \%$ of the dependent variable that is limiting fraud and its effects on financial statements in Jordanian public shareholding companies. This indicates that other variables have not been included in the study model that is responsible for $89 \%$ of limiting fraud and its effects on financial statements in Jordanian public shareholding companies. The regression model is statistically significant as SIG. value equals 0.000 which is less than 0.05 implying that the model is statistically accepted. As well as, the value of the Sig-T was statistically significant at $\alpha \leq 0.05$ was $(0.000)$ and the value of the beta coefficient equals $(0.413)$ which means that the null hypothesis is rejected. So that providing the investigation services have a positive impact in limiting fraud and its effects on financial statements in Jordanian public shareholding companies. This indicates that when the possibility of providing investigation services is increased by one unit, then limiting fraud will be increased by $(11 \%)$.

Based on these results, the alternative hypothesis will be accepted that states "the possibility of providing investigation services have a statistically significant impact in limiting fraud processes and its effects on financial statements in Jordanian public shareholding companies from the viewpoints of the judiciary and the certified public accountant at $\propto \leq 0.05$."

2. The results of the test the second sub-hypothesis that states "the possibility of providing legal support services for applying forensic accounting has no statistically significant impact in limiting fraud processes and its effects on financial statements in Jordanian public shareholding companies from the viewpoints of the judiciary and the certified public accountant at $\propto \leq 0.05$." To verify the validity of this hypothesis, a simple regression equation was applied to study the impact of providing legal support services for applying forensic accounting to limit fraud and its effects on financial statements in Jordanian public shareholding companies, as illustrated in Table 3.

Table 3. The results of applying simple linear regression to test the second sub-hypothesis

\begin{tabular}{lllll}
\hline Dependent variable & Independent variable & Beta & T & Sig. \\
\hline & Constant & 1.009 & 10.290 & .000 \\
\hline \begin{tabular}{l} 
Limiting fraud and its effects \\
on financial statements in \\
\multirow{2}{*}{$\begin{array}{l}\text { Jordanian public } \\
\text { shareholding companies }\end{array}$}
\end{tabular} & providing legal support services & .390 & 7.571 & .000 \\
\cline { 2 - 6 } & $\mathrm{R}^{2}$ & .152 & & \\
\cline { 2 - 6 } & $\mathrm{F}$ & 57.325 & & \\
\hline
\end{tabular}

Table 3 illustrates the results of the simple regression equation to test the second sub-hypothesis; it is obvious that there is a statistically significant impact of providing legal support services in limiting fraud and its effects on financial statements in Jordanian public shareholding companies. Since $\mathrm{R}^{2}$ interpretive value equals $15.2 \%$, the investigation services have interpreted $15.2 \%$ of the dependent variable that is limiting fraud and its effects on financial statements in Jordanian public shareholding companies. This indicates that other variables have not been included in the study model that is responsible for $84.8 \%$ of limiting fraud and its effects on financial statements in Jordanian public shareholding companies. The regression model is statistically significant as SIG. value equals 0.000 which is less than 0.05 implying that the model is statistically accepted. As well as, the value of the Sig-T was statistically significant at $\alpha \leq 0.05$ was $(0.000)$ and the value of the beta coefficient equals $(0.390)$ which means that the null hypothesis is rejected. So that providing legal support services have a positive impact in limiting fraud and its effects on financial statements in Jordanian public shareholding companies. This indicates that when the possibility of providing legal support services is increased by one unit, then limiting fraud will be increased by $(15.2 \%)$.

Based on these results, the alternative hypothesis will be accepted that states "the possibility of providing legal support services has a statistically significant impact in limiting fraud processes and its effects on financial statements in Jordanian public shareholding companies from the viewpoints of the judiciary and the certified public accountant at $\propto \leq 0.05$."

\subsection{Results Related to Testing the Second Main Hypothesis}

The second main hypothesis states "the possibility of providing the components of applying Forensic accounting has no statistically significant impact in limiting fraud processes and its effects on financial statements in Jordanian public shareholding companies from the viewpoints of the judiciary and the certified public accountant at $\propto \leq$ 


\subsection{5.}

To verify the validity of this hypothesis, a simple regression equation was applied to study the impact of the dimensions of providing the components for applying forensic accountability (Skills, Experiences, and Characteristics) to limit fraud and its effects on financial statements in Jordanian public shareholding companies, as illustrated in Table 4.

Table 4. The results of applying simple linear regression to test the second main hypothesis

\begin{tabular}{|c|c|c|c|c|c|}
\hline Dependent variable & Independent variable & Beta & $\mathrm{T}$ & Sig. & VIF \\
\hline & Constant & .477 & 4.377 & 0.000 & \\
\hline \multirow{4}{*}{\begin{tabular}{lcc} 
Limiting & fraud & and its \\
effects & on & financial \\
statements & in & Jordanian \\
public & \multicolumn{2}{c}{ shareholding } \\
companies & \multicolumn{2}{c}{}
\end{tabular}} & $\begin{array}{l}\text { Providing the components for } \\
\text { applying forensic accountability }\end{array}$ & .714 & 11.719 & 0.000 & 1.000 \\
\hline & $\mathrm{R}^{2}$ & \multicolumn{4}{|l|}{.300} \\
\hline & $\mathrm{F}$ & \multicolumn{4}{|c|}{137.326} \\
\hline & SIG & \multicolumn{4}{|c|}{0.0000} \\
\hline
\end{tabular}

Table 4 illustrates the results of the simple regression equation to test the second main hypothesis; it is obvious that there is a statistically significant impact of providing the components of applying forensic accounting in limiting fraud and its effects on financial statements in Jordanian public shareholding companies. Since $\mathrm{R}^{2}$ interpretive value equals $30 \%$, the independent variables of the dimensions of providing the components of applying forensic accounting which include: Skills, Experiences, and Characteristics have interpreted $30 \%$ of the dependent variable that is limiting fraud and its effects on financial statements in Jordanian public shareholding companies. This indicates that other variables have not been included in the study model that is responsible for $70 \%$ of limiting fraud and its effects on financial statements in Jordanian public shareholding companies. The regression model is statistically significant as SIG. value equals 0.000 which is less than 0.05 implying that the model is statistically accepted. According to the value of VIF that is less than 5 implying all dimensions of the dependent variable are accepted and there is no Collinearity problem between the variables. As well as, the value of the Sig-T was statistically significant at $\alpha \leq 0.05$ was $(0.000)$ and the value of the beta coefficient equals $(0.714)$ which means that the null hypothesis is rejected. So that providing the components of applying forensic accounting has a positive impact on limiting fraud and its effects on financial statements in Jordanian public shareholding companies. This indicates that when the possibility of providing the components of applying forensic accounting is increased by one unit, then limiting fraud will be increased by $(30 \%)$.

Based on these results, the alternative hypothesis will be accepted that states "the possibility of providing the components of applying forensic accounting has a statistically significant impact in limiting fraud processes and its effects on financial statements in Jordanian public shareholding companies from the viewpoints of the judiciary and the certified public accountant at $\propto \leq 0.05$."

\subsubsection{Results Related to Testing the Sub-hypothesis of the Second Main Hypothesis}

1- the results of the test the first sub-hypothesis that states "the possibility of providing the appropriate skills and practical experience that must be enjoyed by the forensic accountant to apply forensic accounting has no statistically significant impact in limiting fraud processes and its effects on financial statements in Jordanian public shareholding companies from the viewpoints of the judiciary and the certified public accountant at $\propto \leq 0.05$."

To verify the validity of this hypothesis, a simple regression equation was applied to study the impact of providing the appropriate skills and practical experience that must be enjoyed by the forensic accountant to apply forensic accounting to limit fraud and its effects on financial statements in Jordanian public shareholding companies, as illustrated in Table 5.

Table 5. The results of applying simple linear regression to test the first sub-hypothesis

\begin{tabular}{lllll}
\hline Dependent variable & Independent variable & Beta & T & Sig. \\
\hline & Constant & .712 & 6.459 & .000 \\
\hline
\end{tabular}




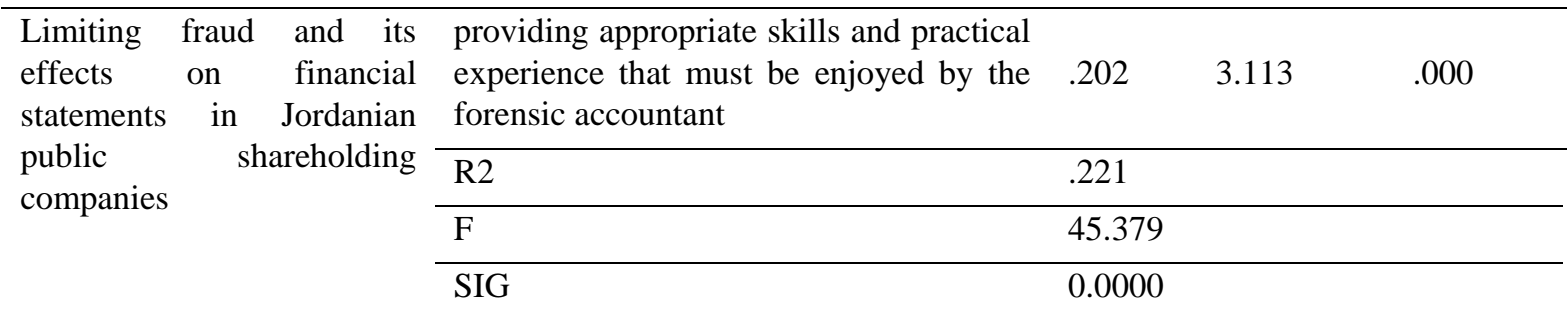

Table 5 illustrates the results of the simple regression equation to test the first sub-hypothesis; it is obvious that there is a statistically significant impact of providing the appropriate skills and practical experience that must be enjoyed by the forensic accountant to apply forensic accounting in limiting fraud and its effects on financial statements in Jordanian public shareholding companies. Since $\mathrm{R}^{2}$ interpretive value equals $22.1 \%$, the appropriate skills and practical experience have interpreted $22.1 \%$ of the dependent variable that is limiting fraud and its effects on financial statements in Jordanian public shareholding companies. This indicates that other variables have not been included in the study model that is responsible for $77.9 \%$ of limiting fraud and its effects on financial statements in Jordanian public shareholding companies. The regression model is statistically significant as SIG. value equals 0.000 which is less than 0.05 implying that the model is statistically accepted. As well as, the value of the Sig-T was statistically significant at $\alpha \leq 0.05$ was (0.000) and the value of the beta coefficient equals $(0.202)$ which means that the null hypothesis is rejected. So that providing the appropriate skills and practical experience that must be enjoyed by the forensic accountant to apply forensic accounting has a positive impact on limiting fraud and its effects on financial statements in Jordanian public shareholding companies. This indicates that when the possibility of providing the appropriate skills and practical experience that must be enjoyed by the forensic accountant to apply forensic accounting by one unit, then limiting fraud will be increased by $(22.1 \%)$.

Based on these results, the alternative hypothesis will be accepted that states "the possibility of providing the appropriate skills and practical experience that must be enjoyed by the forensic accountant to apply forensic accounting has a statistically significant impact in limiting fraud processes and its effects on financial statements in Jordanian public shareholding companies from the viewpoints of the judiciary and the certified public accountant at $\propto \leq 0.05$."

2. the results of the test the second sub-hypothesis that states "the possibility of providing the characteristics that must be enjoyed by the forensic accountant to apply forensic accounting has no statistically significant impact in limiting fraud processes and its effects on financial statements in Jordanian public shareholding companies from the viewpoints of the judiciary and the certified public accountant at $\propto \leq 0.05$."

To verify the validity of this hypothesis, a simple regression equation was applied to study the impact of providing characteristics that must be enjoyed by the forensic accountant to apply forensic accounting to limit fraud and its effects on financial statements in Jordanian public shareholding companies, as illustrated in Table 6.

Table 6 . The results of applying simple linear regression to test the second sub-hypothesis

\begin{tabular}{lllll}
\hline Dependent variable & Independent variable & Beta & T & Sig. \\
\hline & Constant & .677 & 7.483 & .000 \\
\hline $\begin{array}{l}\text { Limiting fraud and its effects } \\
\text { on financial statements in } \begin{array}{c}\text { in } \\
\text { Jordanian } \\
\text { shareholding companies }\end{array}\end{array}$ & $\begin{array}{l}\text { providing characteristics that must be } \\
\text { enjoyed by the forensic accountant }\end{array}$ & .615 & 11.991 & .000 \\
\cline { 2 - 5 } & $\mathrm{R}^{2}$ & .309 & \\
\cline { 2 - 5 } & $\mathrm{F}$ & 143.78 & \\
\cline { 2 - 5 } & SIG & 0.0000 & \\
\hline
\end{tabular}

Table 6 illustrates the results of the simple regression equation to test the second sub-hypothesis; it is obvious that there is a statistically significant impact of the characteristics that must be enjoyed by the forensic accountant in limiting fraud and its effects on financial statements in Jordanian public shareholding companies. Since $\mathrm{R}^{2}$ interpretive value equals $30.9 \%$, the investigation services have interpreted $30.9 \%$ of the dependent variable that is 
limiting fraud and its effects on financial statements in Jordanian public shareholding companies. This indicates that other variables have not been included in the study model that is responsible for $69.1 \%$ of limiting fraud and its effects on financial statements in Jordanian public shareholding companies. The regression model is statistically significant as SIG. value equals 0.000 which is less than 0.05 implying that the model is statistically accepted. As well as, the value of the Sig-T was statistically significant at $\alpha \leq 0.05$ was $(0.000)$ and the value of the beta coefficient equals (0.615) which means that the null hypothesis is rejected. So that providing characteristics that must be enjoyed by the forensic accountant has a positive impact on limiting fraud and its effects on financial statements in Jordanian public shareholding companies. This indicates that when the possibility of providing characteristics that must be enjoyed by the forensic accountant is increased by one unit, then limiting fraud will be increased by $(15.2 \%)$.

Based on these results, the alternative hypothesis will be accepted that states "the possibility of providing characteristics that must be enjoyed by the forensic accountant has a statistically significant impact in limiting fraud processes and its effects on financial statements in Jordanian public shareholding companies from the viewpoints of the judiciary and the certified public accountant at $\propto \leq 0.05$."

\subsection{Results Related to Testing the Third Main Hypothesis}

The third main hypothesis states, "the applicability of forensic accounting procedures and activities as an independent external profession has no statistically significant impact in limiting fraud processes and its effects on financial statements in Jordanian public shareholding companies from the viewpoints of the judiciary and the certified public accountant at $\propto \leq 0.05$."

To verify the validity of this hypothesis, a simple regression equation was applied to study the impact of the dimensions of the applicability of forensic accounting procedures and activities as an independent external profession to limit fraud and its effects on financial statements in Jordanian public shareholding companies, as illustrated in Table 7.

Table 7. The results of applying simple linear regression to test the third main hypothesis

\begin{tabular}{|c|c|c|c|c|c|}
\hline Dependent variable & Independent variable & Beta & $\mathrm{T}$ & Sig. & VIF \\
\hline & Constant & .407 & 4.687 & 0.000 & \\
\hline \multirow{4}{*}{$\begin{array}{lr}\text { Limiting fraud and its } \\
\text { effects on } & \text { financial } \\
\text { statements } & \text { in } \\
\text { Jordanian } & \text { public } \\
\text { shareholding } & \\
\text { companies } & \end{array}$} & $\begin{array}{l}\text { applicability of forensic accounting } \\
\text { procedures and activities as an } \\
\text { independent external profession }\end{array}$ & .725 & 15.656 & 0.000 & 1.000 \\
\hline & $\overline{\mathrm{R}^{2}}$ & .433 & & & \\
\hline & $\mathrm{F}$ & 245.115 & & & \\
\hline & SIG & 0.0000 & & & \\
\hline
\end{tabular}

Table 7 illustrates the results of the simple regression equation to test the third main hypothesis; it is obvious that there is a statistically significant impact of the applicability of forensic accounting procedures and activities as an independent external profession in limiting fraud and its effects on financial statements in Jordanian public shareholding companies. Since $\mathrm{R}^{2}$ interpretive value equals $43.3 \%$, the independent variables of the dimensions of the applicability of forensic accounting procedures and activities as an independent external profession have interpreted $43.3 \%$ of the dependent variable that is limiting fraud and its effects on financial statements in Jordanian public shareholding companies. This indicates that other variables have not been included in the study model that is responsible for $56.7 \%$ of limiting fraud and its effects on financial statements in Jordanian public shareholding companies. The regression model is statistically significant as SIG. value equals 0.000 which is less than 0.05 implying that the model is statistically accepted. According to the value of VIF that is less than 5 implying all dimensions of the dependent variable are accepted and there is no Collinearity problem between the variables. As well as, the value of the Sig-T was statistically significant at $\alpha \leq 0.05$ was $(0.000)$ and the value of the beta coefficient equals $(0.725)$ which means that the null hypothesis is rejected. So that the applicability of forensic accounting procedures and activities as an independent external profession has a positive impact on limiting fraud and its effects on financial statements in Jordanian public shareholding companies. This indicates that when the applicability of forensic accounting procedures and activities as an independent external profession is increased by one unit, then 
limiting fraud will be increased by (43.3\%).

Based on these results, the alternative hypothesis will be accepted that states "the applicability of forensic accounting procedures and activities as an independent external profession has a statistically significant impact in limiting fraud processes and its effects on financial statements in Jordanian public shareholding companies from the viewpoints of the judiciary and the certified public accountant at $\propto \leq 0.05 . "$

\subsection{Results Related to Testing the Fourth Main Hypothesis}

The fourth main hypothesis states, "there are no statistical differences in the dimensions of forensic accounting attributed to the job title (judicial authority and the certified public accountant) at $\propto \leq 0.05$." Before testing this hypothesis, it has been confirmed whether the independent variables are normally distributed around the dependent variable, as shown in Table 8.

Table 8. Results for testing normality

\begin{tabular}{llllll}
\hline \multicolumn{2}{l}{ Kolmogorov-Smirnov test } & \multicolumn{5}{l}{ Shapiro-Wilk Test } \\
\hline Statistic & $\mathrm{df}$ & Sig. & Statistic & Df & Sig. \\
\hline .106 & 323 & .000 & .944 & 323 & .000 \\
\hline
\end{tabular}

Table 8 illustrates that the data is not normally distributed, as the Sig. value for both tests is less than 0.05 so data is not following a normal distribution. Gujarati (2009) assumes that data is normally distributed if and only if the Sig. value 0.05 or more for the Kolmogorov-Smirnov test and Shapiro-Wilk test. To check the validity of this hypothesis, Non-parametric Kruskal Wallis Test was applied, as recommended by (Gujarati, 2009) not T-test for independent samples in case data is not normally distributed as shown in Table 9.

Table 9. Kruskal Wallis test for testing the fourth hypothesis

\begin{tabular}{|c|c|c|c|c|c|c|}
\hline Variable & Job & $\begin{array}{l}\text { No. of } \\
\text { respondents }\end{array}$ & Mean & S.D. & $\begin{array}{l}\text { Kruskal } \\
\text { Wallis SIG. }\end{array}$ & $\begin{array}{l}\text { Convenien } \\
\text { ce Degree }\end{array}$ \\
\hline \multirow[t]{2}{*}{ Investigation services } & $\begin{array}{l}\text { Certified public } \\
\text { accountant }\end{array}$ & 217 & 3.88 & 0.41 & 0.000 & High \\
\hline & Judicial authority & 106 & 3.67 & .390 & & High \\
\hline \multirow[t]{2}{*}{ Legal Support Services } & $\begin{array}{l}\text { Certified public } \\
\text { accountant }\end{array}$ & 217 & 3.93 & .520 & 0.000 & High \\
\hline & Judicial authority & 106 & 3.62 & .480 & & Moderate \\
\hline \multirow{2}{*}{$\begin{array}{l}\text { Possibility of providing the } \\
\text { requirements for applying } \\
\text { forensic accounting }\end{array}$} & $\begin{array}{l}\text { Certified public } \\
\text { accountant }\end{array}$ & 217 & 3.91 & .410 & .0000 & High \\
\hline & Judicial authority & 106 & 3.64 & 0.39 & & Moderate \\
\hline \multirow[t]{2}{*}{$\begin{array}{l}\text { Possibility of providing } \\
\text { Skills }\end{array}$} & $\begin{array}{l}\text { Certified public } \\
\text { accountant }\end{array}$ & 217 & 3.83 & 0.50 & 0.000 & High \\
\hline & Judicial authority & 106 & 3.59 & 0.39 & & Moderate \\
\hline \multirow[t]{2}{*}{$\begin{array}{l}\text { Possibility of providing } \\
\text { experiences }\end{array}$} & $\begin{array}{l}\text { Certified public } \\
\text { accountant }\end{array}$ & 217 & 3.83 & 0.46 & 0.000 & High \\
\hline & Judicial authority & 106 & 3.69 & 0.52 & & High \\
\hline \multirow{2}{*}{$\begin{array}{l}\text { Possibility of providing } \\
\text { Characteristics }\end{array}$} & Judicial authority & 217 & 3.79 & .480 & 0.000 & High \\
\hline & $\begin{array}{l}\text { Certified public } \\
\text { accountant }\end{array}$ & 106 & 3.51 & .420 & & Moderate \\
\hline \multirow{2}{*}{$\begin{array}{l}\text { Possibility of providing the } \\
\text { components of applying }\end{array}$} & Judicial authority & 217 & 3.82 & .390 & 0.000 & High \\
\hline & Certified public & 106 & 3.60 & .380 & & Moderate \\
\hline
\end{tabular}




\begin{tabular}{|c|c|c|c|c|c|c|}
\hline Forensic accounting & accountant & & & & & \\
\hline \multirow{2}{*}{$\begin{array}{lr}\text { Applicability of } & \text { forensic } \\
\text { accounting procedures as an } \\
\text { independent } & \text { external } \\
\text { profession } & \end{array}$} & Judicial authority & 217 & 3.92 & .520 & 0.000 & High \\
\hline & $\begin{array}{l}\text { Certified public } \\
\text { accountant }\end{array}$ & 106 & 3.68 & .470 & & High \\
\hline \multirow{2}{*}{$\begin{array}{lr}\text { applicability } \text { of } & \text { forensic } \\
\text { accounting activities as an } \\
\text { independent } & \text { external } \\
\text { profession } & \end{array}$} & Judicial authority & 217 & 3.88 & .550 & 0.000 & High \\
\hline & $\begin{array}{l}\text { Certified public } \\
\text { accountant }\end{array}$ & 106 & 3.61 & .470 & & Moderate \\
\hline \multirow{2}{*}{$\begin{array}{l}\text { Applicability of forensic } \\
\text { accounting procedures and } \\
\text { activities as an independent } \\
\text { external profession }\end{array}$} & Judicial authority & 217 & 3.90 & .480 & .0000 & High \\
\hline & $\begin{array}{l}\text { Certified public } \\
\text { accountant }\end{array}$ & 106 & 3.64 & 0.42 & & Moderate \\
\hline
\end{tabular}

Table 9 shows that all dimensions of forensic accounting are significant. The significance value of the three dimensions and their axes was less than (0.05) respectively. All these values are less than the acceptance of the alternative hypothesis at a significance level less than (0.05). Based on the results of (Kruskal Wallis) of the fourth main hypothesis, the study concluded the following:

1. There is a difference in the opinions of the two samples in terms of the possibility of providing the requirements for applying forensic accounting, as this axis was more important for the accountants with an arithmetic mean of (3.91) indicating high importance than for the judicial authority with an arithmetic mean of (3.64) indicating moderate importance.

2. There is a difference in the opinions of the two samples in terms of the possibility of providing the components of applying forensic accounting, as this axis was more important for the accountants with an arithmetic mean of (3.82) indicating high importance than for the judicial authority with an arithmetic mean of (3.60) indicating moderate importance.

3. There is a difference in the opinions of the two samples in terms of the possibility of providing the applicability of forensic accounting procedures and activities as an independent external profession, as this axis was more important for the accountants with an arithmetic mean of (3.90) indicating high importance than for the judicial authority with an arithmetic mean of (3.64) indicating moderate importance.

Based on these results, the null hypothesis is rejected and the alternative hypothesis is accepted which states "there are statistical differences in the dimensions of Forensic accounting attributed to the job title (judicial authority, certified public accountant) at $\propto \leq 0.05$. This indicates that Certified public accountants are more concerned with forensic accounting and its dimension than judicial authority. This could be attributed to the Certified public accountants' nature and understanding of the importance of forensic accounting as a control and a professional field whereas for judicial authority it is a mere job and this attributed to the fact that judicial authority has no trust in any entity that is not accredited by Jordanian Judicial Council or because they are not fully aware of the concept of forensic accounting and its importance in various fields.

\section{Conclusions and Recommendations}

1. Results of the first main hypothesis test: indicates that the perception of the sample of the study that the requirements of applying forensic accounting, which includes investigation services and legal support services can be available in the Jordanian environment to contribute to limit the fraud and its effects on the financial statements of Jordanian companies public share by (16.7\% ), As shown in Table 1, which confirms the important and effective role of these services in reducing fraud and its contribution to resolving various cases and disputes related to criminal cases as a modern mechanism that contributes to the control and control of the quality of data appeared in the financial statements to confirm the confidence and credibility with stakeholders, which in turn will reflect positively on the internal and external business for various business organizations and many judicial authorities and regulatory entities in the Jordanian environment. This result has the following sub-results:

a. The results of the first sub-hypothesis test: The perceptions of the sample of the study indicate that it is possible to provide investigation services in the Jordanian environment because it has an important and effective role in reducing frauds and its effects on the financial statements of Jordanian public shareholding companies by $11 \%$ 
as in table 2, which confirms that investigation services contribute to the compilation of appropriate shreds of evidence to resolve disputes concerning illegal activities and to identify whether frauds have occurred as well as to identify the parties responsible for them, in addition to their contribution in resolving various issues and disputes related criminal financial suits.

b. The perceptions of the sample of the study indicate that it is possible to provide legal support services in the Jordanian environment because it has an important and effective role in reducing frauds and its effects on the financial statements of Jordanian public shareholding companies by $15.2 \%$ as in table 3 , which confirms that the legal support services contribute the service of providing the expert witness to assist and to support the judicial authorities in carrying out legal procedures and provide a technical or scientific opinion in the case in dispute, and to provide the services of the consultant to assist the judicial authorities in developing Strategies based on reducing fraud and prosecuting those who committed it.

2. The results of the second main hypothesis test: The perceptions of the sample of the study indicate the possibility of providing the components of applying forensic accounting in the Jordanian environment, which includes the appropriate characteristics, skills, and practical experience because of their important and effective role in reducing the fraud and its effects on the financial statements in Jordanian companies by (30\%), as shown in Table (4), which confirms that providing the components of applying forensic accounting contribute greatly to enhance the capabilities of the forensic accountant so that he can perform the tasks required of him in the best way. This result has the following sub-results:

a. The results of the first sub-hypothesis test: The perceptions of the sample of the study indicate that it is possible to provide skills and practical experience in the Jordanian environment because it has an important and effective role in reducing the frauds and its effects on the financial statements in the Jordanian public shareholding companies by $22.1 \%$ Table 5 shows that the provision of new and diverse skills and expertise contributes to a balance of knowledge that enhances the forensic accountant's abilities and improves his performance to be able to cope with current and future challenges.

b. Results of the second sub-hypothesis test: The perceptions of the sample of the study indicate the possibility of providing characteristics in the Jordanian environment because of their important and effective role in reducing the fraud and its effects on the financial statements of the Jordanian public shareholding companies by (30.9\%) as shown in Table 6, Which confirms that the characteristics enjoyed by the forensic accountant contribute to reducing the illegal and doubtful professional practices of managers, accountants, and auditors and thus reduce the practices of fraud, so these characteristics must be enjoyed by the forensic accountant to fill all the gaps that cause these illegal practices.

3. The results of the third main hypothesis test: The perceptions of the sample of the study indicate the possibility of providing the procedures and activities of criminal accounting as an independent external profession in the Jordanian environment because it has an important and effective role in reducing frauds and its effects on the financial statements of Jordanian companies public shareholding by $43.3 \%$ as shown in Table 7 , which means that the practice of forensic accounting procedures and the application of their activities by the forensic accountant independently of the decisions, pressures, and interests of corporate administrations is an important and essential element in reducing fraud.

4. The results of the fourth main hypothesis test indicate that there is a difference between the perspectives of the two samples in terms of:

a. The extent to which the requirements for the application of forensic accounting can be provided.

b. The possibility of providing the components of applying forensic accounting.

c. The extent of the applicability of forensic accounting procedures and activities as an independent external profession.

This indicates that chartered public accountants are more interested in forensic accounting and its axis than the judiciary. This may be due to the nature of legal accountants' perception and understanding of the importance of forensic accounting as a supervisory and professional field, whereas the judiciary may regard it as a profession and may be due to lack of confidence in any entity that is not accredited by the Jordanian Judicial Council, or because they are not fully aware of the concept of forensic accounting and its importance in various fields.

\section{Recommendations}

1. To work towards the adoption of the requirements and components of applying forensic accounting by the 
responsible professional organizations, such as the Jordanian Chartered Accountants Association and the Department of Corporate Business Control, through holding various training courses to develop the capabilities of accounting students and accountants to encourage them to possess the necessary expertise, skills, and characteristics that qualify them to practice forensic accounting as an independent foreign profession, similar to developed foreign countries.

2. The establishment of a formal and independent professional association for forensic accountants to establish accounting standards and legislation related to forensic accounting and activate them, such as the issuance of the standard (forensic accounting and conditions of practice) to include all the procedures and conditions required to apply forensic accounting in private and public companies in the Jordanian environment, independently of chartered public accountants.

3. To raise the awareness of the judicial authorities about the concept of forensic accounting and its importance in resolving cases related to financial criminal cases, and its contribution to rationalizing judges' judgments through the provision of research and investigation services, consulting services and expert witness services.

4. The inclusion of forensic accounting in the curricula of Jordanian universities to raise awareness about this new field to establish accountants to meet the future needs of the labor market.

5. To conduct further research to develop this concept and expand it, such as studying the obstacles that may face the application of forensic accounting in the Jordanian environment, and studying the possibility of drafting special standards for the application of forensic accounting in the Jordanian environment, Tax evasion, or studying the applicability of forensic accounting to increase the quality of accounting disclosure in the financial statements.

\section{References}

Aduwo, O. O. (2016).The Role of Forensic Accounting in Combating the Menace of Corporate. International Journal of Economics, Commerce and Management, 4 (1), 640-649. Retrieved from http://ijecm.co.uk/wp-content/uploads/2016/01/4138.pdf

Ahmed, A. M. A. (2013). Analytical study of the role of judicial accounting in the development of accounting mechanisms to combat financial and administrative corruption by applying to companies listed on the Egyptian stock exchange. Journal of Accounting and Auditing, 1 (2), 40-1.

Ahmed, K. M. A. (2013). The Role of Judicial Accounting in Reducing Financial Corruption Practices. Paper presented to the First International Conference on Accounting and Auditing, Faculty of Commerce, BeniSuef University, Egypt.

Alkubaisi, A. S. (2016). Field Survey on Judicial Accountability from Judicial and Judicial Auditors in Jordan. Jordanian Journal of Business Administration, 12(1), 29-1.

Al-said, Y. (2010). The Role of Judicial Accounting in the Settlement of Commercial Disputes and its Impact at the National Level. Retrieved from www.Scribed.com

American Institute of Certified Public Accountants (AICPA). (2006). Special Report: Forensic Procedures \& Specialists: Useful Tools \& Techniques. Retrieved fromhttp://www.AICPA.org

Augustine, E. A., \& Uagbale-Ekatah, R. E. (2014). The Growing Relevance of Forensic Accounting as a Tool for Combating Fraud and Corruption: Nigeria Experience. Research Journal of Finance and Accounting, 5(2), 71-77. Retrieved fromhttps://pdfs.semanticscholar.org/f5b9/81e2087a5351b364a9f79f7187b60364afe2.pdf

Blessing, I. N. (2015). Empirical Analysis of the Use of Forensic Accounting Techniques in Curbing Creative Accounting. International Journal of Economics, Commerce and Management, 3(1), 1-15. Retrieved fromhttp://ijecm.co.uk/wp-content/uploads/2015/01/3127.pdf

Domino, M. A., Giordano, G., \&Webinger, M. (2017). An Investigation of the Factors that Impact the Perceived Value of Forensic Accounting Certifications. Journal of Forensic and Investigative Accounting, 9(1), 637-653.Retrieved fromhttp://abfa.us/wp-content/uploads/2017/01/Full-Article-Forensic-Accounting-Certifications.pdf

Gujarati, D. N. (2009). Basic Econometrics.Tata McGraw-Hill Education.

Hegazy, S., Sangster, A., \& Kotb, A. (2017). Mapping Forensic Accounting in the UK. Journal of International Accounting, Auditing and Taxation, 28, 43-56.Http://doi.org/10.1016/j.intaccaudtax.2016.12.004

Islam, M. J., Rahman, M. H., \& Hossan, M. T. (2011). Forensic Accounting as a Tool for Detecting Fraud and Corruption: An Empirical Study in Bangladesh. ASA University Review, 5(2), 77-85. 
Jalili, M. A. (2012). Judicial Accountability and Applicability in Iraq. Journal of the development of Rafidain, 34(107), 21-9.https://doi.org/10.33899/tanra.2012.162021

Jubouri, N., \& Khalidi, S. (2013). The role of Judicial Accounting in the Detection of Financial Fraud. Journal of Economic and Administrative Sciences, 19(70), 473-457.

Khalidi, N. N. M. (2014). The Role of Judicial Accounting in the Face of Creative Accounting Practices and Reducing Their Impact on the Financial Statements. Journal of Palestine University for Research and Studies, 6(6), 50-9.

Khalil, M. A. I. (2017). Developing the Role of Judicial Review to Counter Fraud, Fraud, and Financial Corruption in Business Organizations and Achieving the Reliability of Accounting Information - A Test Study. Journal of Accounting and Auditing, 5( 1), 236-197.

Monouf, R. A. (2011). The role of Judicial Review in Activating the Principles of Corporate Governance: a Theoretical Field Study. Journal of Financial and Commercial Research, 1 (1), 97-70.

Radi, M. S. (2011). Advanced Audit Encyclopedia, Judicial Review, Environmental Performance Review, Corporate Governance Review, Audit Quality. I. University Education House. Alexandria. Egypt.

Saad, S. A. (2013). Judicial Accounting in Saudi Arabia: Current Practice and Future Perspective: An Exploratory Study. Journal of King Abdulaziz University, 27(1), 94-3.

Singleton, T. W., Singleton, A. J., Bologna, G. J., \& Lindquist, R. J. (2010). Fraud Auditing and Forensic Accounting. Wiley \& Sons, Fourth Edition.https://doi.org/10.1002/9781118269183 